\title{
Thinking through Content Instruction: Microteaching Unveils
}

\author{
Nor Hashimah Isa \\ Department of English Language and Literature, Faculty of Languages and Communication, Universiti Pendidikan \\ Sultan Idris, Tanjung Malim, Perak, Malaysia \\ Email: shima6655@yahoo.com \\ Hj. Kamaruzaman Jusoff \\ Department of Forest Production, Faculty of Forestry, Universiti Putra Malaysia, Serdang 43400, Selangor, Malaysia \\ Email: kjusoff@yahoo.com
}

\begin{abstract}
This paper investigates the extent of critical skills being incorporated in the undergraduates' lesson as shown in their microteaching sessions. The researcher seeks to find evidence of critical thinking skills in the undergraduates' content instruction of their respective lessons. She investigates the integration of critical thinking skills via the undergraduates' lesson plans and the lesson's implementation. She seeks for inclusion of these skills by viewing the taped lessons. Recommendations to UPSI are also presented in an effort to inspire awareness on the compelling need for thinkers amongst undergraduates and future teachers.
\end{abstract}

Index Terms — critical thinking, content, instruction, skills, microteaching

\section{INTRODUCTION}

Critical thinking (CT) is higher order thinking and it involves skills. We use critical thinking when we are trying to make decisions or solve problems in our daily lives. Decision making is a thoughtful process of choosing a variety of options for acting or thinking (Freeley \& Steinberg, 2008). They stress further that in critical thinking the decider in decision making makes a choice. Undeniably, critical thinking is a vital skill and ability that can assist us in difficult times at work or at home. Bassham et.al (2005) define critical thinking (CT) as 'a wide range of cognitive skills and intellectual dispositions needed to effectively identify, analyze, and evaluate arguments and truth claims; to discover and overcome personal prejudices and biases; to formulate and present convincing reasons in support of conclusions; and to make reasonable, intelligent decisions about what to believe and what to do.' Freiberg and Driscoll (1992) see critical thinking (CT) as the ability and disposition to make and assess conclusion based on evidence and it is a process for determining the value of an idea, a concept, a solution or information. Paul and Elder (2001) say 'development in thinking requires a gradual process requiring plateaus of learning and just plain hard work. It is not possible to become an excellent thinker simply because one wills it. They believe that it will take years. Hence, it is undisputedly true that critical thinking is cognitive skill to identify, analyze and problem solving for the goodness of everyone involved. It requires a long time to materialize. In so doing, disposition to critical thinking is very much needed as it is an inclination to think critically and to make use of its fundamentals in solving problems, supporting an argument or making decisions.

Bassham et. al (2005) provides justifications why critical thinking is important in the classroom. They believe the focus at the universities or colleges is higher-order thinking. They go on further to say that the students learn a variety of skills that can immensely improve their performance in the classrooms. These skills are about arguments and beliefs of others where they understand them, critically evaluate them and develop and defend their own well-supported ones. Lett (2010) a college professor says that most of the freshman and sophomore students in his classes simply do not know how to draw reasonable conclusions from the evidence although they've been taught in high school what to think; few of them know how to think. He declares:

In an attempt to remedy this problem at my college, I've developed an elective course called "Anthropology and the Paranormal." The course examines the complete range of paranormal beliefs in contemporary American culture, from precognition and psychokinesis to channeling and cryptozoology and everything between and beyond, including astrology, UFOs, and creationism. I teach the students very little about anthropological theories and even less about anthropological terminology. Instead, I try to communicate the essence of the anthropological perspective, by teaching them, indirectly, what the scientific method is all about. I do so by teaching them how to evaluate evidence.

Critical thinking is pertinent to be grasped by college or university students as they are pursuing tertiary education. This is undisputedly true as these undergraduates come from diverse cultural backgrounds and they need to be equipped with these critical thinking skills to see opinions and arguments in a healthy way. They will turn out to be more understanding and accommodating persons. Hence, it is pertinent that undergraduates who are future teachers of the English Language in Malaysian secondary schools conscious of the significance of having critical thinking skills and 
imparting them to their students. The thought provoking question is whether these undergraduates are really knowledgeable and aware of their critical thinking skills. Therefore, this paper probes for answer as it is crucial that these future teachers of the English language are aware of the necessity of being equipped with these critical thinking (CT) skills if they wish to bring their secondary students to more doors of possibilities and challenges in the future.

The quality of education that teachers provide to student is highly dependent upon what teachers do in the classroom (Effandi and Zanaton, 2007). Teachers make a difference in their students' lives and this will continue to shape them into fantastic individuals when they become great sons, daughters, fathers, wives and the list goes on. Irrefutably, believing in the greatness of critical thinking (CT) as having the power to change peoples' lives and thinking is much required amongst these university students. Norris (1985) suggests that teachers should check their own awareness and ability to be open to critical thinking from their lessons in order to promote this. This is indeed great advice for these future teachers. Nevertheless, a lecturer can only pray that there is a critical thinking beacon shining in the Malaysian Secondary English Language classrooms emitted by her UPSI graduates. For this reason, she looks for incorporation of critical thinking (CT) and the much awaited disposition of CT in their lessons during the challenging yet entertaining microteaching sessions.

Microteaching in Teaching of English as Second Language (TESL) is part of the undergraduates' coursework for the TESL Methodology 14 week course conducted by the researcher who is a senior lecturer of the Department of English Language and Literature, Faculty of Languages and Communication at Universiti Pendidikan Sultan Idris (UPSI). This is an education university and with this stature UPSI must produce great secondary school teachers who will be mushroomed all over Peninsular and East Malaysia. In order to meet this demand lecturers and undergraduates work together in the transformation of these ignorant souls to effective English Language secondary school teachers. We do not need more teachers to perceive their higher order thinking skills to be inadequate as researched by Rajendran (2001) In his study that focused on the teaching of higher-order thinking skills in language classrooms he found that the teachers possessed significantly different and better attitude towards teaching Malay or English as compared to the teaching of Higher Order thinking skills. These teachers perceived that they were better prepared in terms of their knowledge; pedagogical skills and attitude to teach these subjects as compared to teach higher order thinking skills. Hence, UPSI must ensure that novice teachers who graduated from this institution have the capability and knowledge to teach higher-order thinking skills to their students.

The objective of this paper are three-folds, namely to (a) examine the different levels of critical thinking skills incorporated in the undergraduates' microteaching lessons, (b) study the relationship between having critical thinking skills amongst the undergraduates and carrying out their lesson during the microteaching and (c) determine the possible reasons of undergraduates' refusal to integrate critical thinking and its higher levels in their microteaching lessons.

\section{METHODS}

The undergraduates have to carry out a Microteaching session from week 8 to 12. The microteaching Laboratory equipped with sound proof walls and equipment is the venue as the undergraduates' microteaching lessons are videotaped by the technician. This brings us to the purpose of this paper that is to seek the extent of critical skills being incorporated in the undergraduates' lesson as evident in their microteaching sessions. Prior to their microteaching sessions they received input on critical thinking (CT) and its importance in teaching in their TESL methodology course. In fact, they have also gained knowledge about CT from their education papers offered by the Education Faculty. Therefore, these undergraduates are aware of critical thinking, its different levels and significance in teaching the English Language to Malaysian secondary school students. The researcher hopes to investigate CT being included in their lesson plan and their teaching in Microteaching sessions. They were previously taught to include critical thinking in their lessons and one way to find out if CT is truly given some importance is to analyse their taped lessons and their lesson plans. This is very pertinent because as future teachers of the English Language they must be equipped with critical thinking (CT) skills so that they can train young Malaysians to be more critical, creative and innovative as required by inevitable changes in the highly competitive society. Freiberg and Driscoll (1992) go on to say that "much of the push for thinking skills has resulted from an awareness that we live in a society that requires us to make complex decisions. They also believe in providing specialized preparation for teachers as well as support for their efforts in critical thinking content.

Data for the analysis is the undergraduates' video taped lessons and their lesson plans during the microteaching sessions. Microteaching is the ultimate session where the undergraduates put into practice theories, examples, aids and new ideas that they have acquired from the TESL Methodology course. Critical thinking skills are integrated in the course and undergraduates are repeatedly guided and advised of incorporating them in their lessons. These undergraduates prepare their respective lessons using the stipulated lesson plans and implement the lessons microteaching laboratory where their lessons were videotaped by the technician. Their classmates are given the roles of Malaysian secondary school students depending on the requirements of the 'teachers'. If the 'teacher wants an average Form 1 class then the classmates have to abide and take up the role. The researcher sits at the back and assesses the lessons. At the end of two lessons, she asks the 'teachers' about their strengths and weaknesses of their lessons. She then gives her feedback and suggestions. The researcher then continues observing the other lessons being taught by other undergraduates. 
Later, the researcher views the microteaching via the video-taped lessons, where she analyses the incorporation of critical thinking (CT) embedded in participants' lessons and in their lesson plan. She then looks for the different levels of critical thinking skills such as from the lower to the higher end. To exemplify, identifying is on the lower end while problem solving and making decisions are on the higher end of the critical thinking continuum. She analyses and records the incorporation of CT and its levels in Table 3. Then, she subsequently calculates it to a percentage to see the patterns of the incorporation of the CT and its levels in the participants' lessons.

This is actually the participants or undergraduates' very first experience teaching and they were actually nervous but excited. It has been an interesting experience for the researcher too because she is very anxious to witness knowledge and theories being put into practice. She is even more concerned to see the integration of critical thinking (CT) and its different levels incorporated in their lessons.

The participants of the research are the TESL (Teaching of English as Second Language) major undergraduates of the TESL Methodology course (BIT 2083) Semester 2, 2009/2010. They are from group B and 16 of them from different gender and ethnicity. They participated in the microteaching which was carried out in the microteaching laboratory. They are between 21 to 23 years of age and are in their first semester second year. BIT 2083 is an important course that guides them to be effective English Language secondary school teachers. They will embark on their compulsory Practicum Teaching when they reach semester eight. Therefore, this course is very essential for them as it exposes them to the teaching theories and practices, critical thinking skills and microteaching before they go for their practicum or teaching practice.

\section{RESULTS AND DISCUSSIONS}

There are several significant findings of the research. The undergraduates' microteaching lessons overall do not consist of critical thinking skills of the higher end such as problem solving and making decisions. In fact, their lessons are more inclined to have lower critical thinking skill such as identifying, categorizing and cause and effect. Table 1 explains the findings of the research.

TABLE 1:

THE UNDERGRADUATES' INCORPORATION OF CT AND LEVELS OF CT IN THEIR MICROTEACHING LESSONS

\begin{tabular}{|c|c|c|c|c|}
\hline No. & Undergraduates & $\begin{array}{l}\text { CT in } \\
\text { Lesson } \\
\text { Plan }\end{array}$ & $\begin{array}{l}\text { CT in implementation } \\
\text { of lesson } \\
\text { (Microteaching) }\end{array}$ & Lecturer's Remarks \\
\hline 1 & A & Yes & No & $\begin{array}{l}\text { Lesson: Environment. She did not include CT of Cause \& effect or } \\
\text { 'problem solving'. She merely told a story of a trash can that turned into a } \\
\text { monster and chased them in the field. }\end{array}$ \\
\hline 2 & B & Yes & Yes & $\begin{array}{l}\text { Lesson: Recycle. She did try to elicit students to CT 'cause \& effect'. No } \\
\text { CT 'problem solving. }\end{array}$ \\
\hline 3 & $\mathrm{C}$ & Yes & Yes & $\begin{array}{l}\text { Lesson: Environment. She just talked about changes in the weather and } \\
\text { animal extinction and asked student about changes to their neighborhood } \\
\text { (CT identifying) but did not bring CT cause \& effect' or 'CT problem } \\
\text { solving'. }\end{array}$ \\
\hline 4 & $\mathrm{D}$ & Yes & Yes & $\begin{array}{l}\text { Lesson: Earth. Showed students video clip of M.J's 'Earth Song'. Although } \\
\text { she asked students what caused earth's destruction she did not bring them to } \\
\text { CT problem solving.' }\end{array}$ \\
\hline 5 & $\mathrm{E}$ & Yes & No & $\begin{array}{l}\text { Lesson: Friendship. She showed interesting video animations. She merely } \\
\text { asked her students what they think about the video and friendship. Did not } \\
\text { give a situation that can make students do CT 'cause \& effect' or 'solving } \\
\text { problems'. She actually had interesting games and her students enjoyed her } \\
\text { class. }\end{array}$ \\
\hline 6 & $\mathrm{~F}$ & Yes & No & $\begin{array}{l}\text { Lesson: Environment. She did not have CT 'cause \& effect' or 'Problem } \\
\text { solving'. Her elocution is good. Interesting games though and her students } \\
\text { enjoyed her class }\end{array}$ \\
\hline 7 & G & Yes & Yes & $\begin{array}{l}\text { Lesson: Environment. Merely CT 'identifying.' Very little CT 'cause \& } \\
\text { effect and he did not relate his students' answers to CT 'Problem solving.' }\end{array}$ \\
\hline 8 & $\mathrm{H}$ & Yes & No & Lesson: Air pollution. He carried out interesting games but no CT at all. \\
\hline 9 & I & Yes & Yes & $\begin{array}{l}\text { Lesson: Friendship. She had a good song that is relevant to the lesson and } \\
\text { her students sang well but did not relate their responses to CT ' cause \& } \\
\text { effect' or CT 'problem solving'. }\end{array}$ \\
\hline 10 & $\mathrm{~J}$ & Yes & No & $\begin{array}{l}\text { Lesson: Being great friends. She had interesting games that caught her } \\
\text { students' attentions. Nevertheless, no CT. }\end{array}$ \\
\hline 11 & $\mathrm{~K}$ & Yes & Yes & $\begin{array}{l}\text { Lesson: Healthy foods. She had CT 'identifying' only. Did not have CT } \\
\text { 'cause \& effect' or CT 'problem solving'. }\end{array}$ \\
\hline 12 & $\mathrm{~L}$ & Yes & Yes & $\begin{array}{l}\text { Lesson: Healthy lifestyles. She had interesting games for her students ' } \\
\text { fruits \& vegetables' that is CT 'identifying'. She had CT ' cause \& effect } \\
\text { but no CT 'problem solving.' }\end{array}$ \\
\hline 13 & M & Yes & Yes & $\begin{array}{l}\text { Lesson: Foods. He had CT 'identifying of foods that offer protein, } \\
\text { carbohydrates and vitamins. He also had CT 'cause \& effect' but none on } \\
\text { CT 'problem solving.' }\end{array}$ \\
\hline 14 & $\mathrm{~N}$ & Yes & No & $\begin{array}{l}\text { Lesson: Healthy Foods. He has guessing games but no CT of any level at } \\
\text { all. }\end{array}$ \\
\hline 15 & $\mathrm{O}$ & Yes & Yes & $\begin{array}{l}\text { Lesson: Disabled people. He showed very relevant pictures and video of } \\
\text { disabled people that was actually very moving. He merely discussed the } \\
\text { answers based on the video but did not bring his students to CT 'problem } \\
\text { solving' or CT 'cause \& effect.' }\end{array}$ \\
\hline 16 & $\mathrm{P}$ & Yes & Yes & $\begin{array}{l}\text { Lesson: Caring society. He had interesting pictures of the disabled but he } \\
\text { only had CT 'identifying' of different types of disability. No CT 'cause \& } \\
\text { effect or CT 'problem solving' incorporated. }\end{array}$ \\
\hline
\end{tabular}


It was observed that $100 \%$ of the participants incorporated critical thinking skills (CT) in their lesson plans. A total of $62.5 \%$ of the participants integrated CT in implementation of their microteaching lessons while $37.5 \%$ of the participants did not integrate CT in implementation of their microteaching lessons. Meanwhile, $100 \%$ of the participants who incorporated CT in their microteaching lessons did not include CT 'problem solving' in their microteaching lessons. A total of $90 \%$ of the participants who incorporated CT in their microteaching lessons did not include both CT 'cause \& effect' and CT 'problem solving', while 50\% of the participants who incorporated CT in their microteaching lessons included CT 'cause \& effect.' However, $100 \%$ of the participants who incorporated CT in their microteaching lessons included merely CT 'identifying'.

The participants who are undergraduates of TESL Methodology course did incorporate critical thinking skills in their microteaching lessons but only to a certain extent. Majority of them integrated critical thinking skill 'identifying' which is the lower end, half of them incorporated CT 'cause and effect' while majority too did not include the higher level CT problem solving. Unquestioningly, all of the $62.5 \%$ participants who integrated CT in their microteaching lessons merely used the lower CT that is 'identifying.'

The compelling question is whether these undergraduates are really knowledgeable of critical thinking and its different levels. The researcher is rather disappointed because she did give her input on critical thinking skills and their exemplifications in her class. They did get their input from the education lecturers from the education faculty. So, what went wrong? Why the glaring incomprehensible loopholes? The researcher strongly believes that these undergraduates lack knowledge of creating scenarios of CT in the higher level such as 'cause and effect' and 'problem solving.' Wright (2001) gives an example of a situation where the students can read through and try to solve it.

Example:

In another case, suppose you forgot to put your name (or ID number) on one of the weekly quizzes in certain course (A) and received an unusually low grade on that quizzes (B). This would be a correlation, and you might speculate about how omitting your name might have affected the grade. However, if you also know that you skipped class and did not do the reading for the week, this would be something else that correlated with both A and B. In this context it would be NTD (non-trace data) favoring a chance explanation of the correlation. For lack of preparation would be such a good explanation of the low grade that we need not try to construct weird stories involving your name (p. 252).

He gives a question:

What is the most plausible story you can think of that would connect omitting your name to the grade in this case? What direction of influence does this story have (p. 252)?

He gives an answer:

It depends on your personality. But for most people, perhaps most plausible, would be that you realized you were unprepared and the anxiety or panic or fretting caused you to omit your name. This would be a common cause: being unprepared caused both the bad grade and the omitted name, independently (p. 307).

The above is a clear cut example of a scenario in critical thinking where students or undergraduates of colleges and universities must comprehend, analyse and solve. It is not trivial as the researcher believes such example to be highly incomprehensible to many especially when it is in the English Language. Hence, the undergraduates must be knowledgeable in order to understand critical thinking. Norris (1985) believes that "to think critically, one must have knowledge" (p.308). He agrees that a teacher's first responsibility to his or her students 'critical thinking is development of a knowledge base (p. 308). This is true as without certain knowledge students will not be able to identify, analyse and to solve problems and make decisions. In others words, they are far from being critical thinkers.

Pertaining to the issue of not being knowledgeable in the creation of critical thinking (CT) examples or scenarios, the researcher is aware of the fact that perhaps these undergraduates could have done better if the lessons were in the Malay Language. This medium of instruction is Malaysia's national language and the Malays' first language. This is because one horrendous problem that is ever so burdening them is their proficiency in the English Language. This is so crystal clear regardless of race or gender. Not being proficient and eloquent in the English Language is nothing new if one is to put these TESL undergraduates under the microscope. Critical thinking in the English language would require a certain level of vocabulary and comprehension. This is because according to Freiberg and Driscoll (1992) the fundamentals of critical thinking includes confirming conclusion with facts, identifying bias, propaganda, stereotype, identify assumptions, recognize overgeneralization and identify relevant or irrelevant information.

TABLE 2:

RESPONDENTS' CRITICAL THINKING SKILLS

\begin{tabular}{lll}
\multicolumn{3}{c}{ RESPONDENTS $^{\prime}$ CRITICAL THINKING SKILLS } \\
\hline Skills & Count No. & $\%$ \\
\hline Most unsatisfactory & 66 & .3 \\
Not Satisfactory & 358 & 1.7 \\
Fair & 4730 & 22.1 \\
Satisfactory & 11777 & 55.1 \\
Most Satisfactory & 4438 & 20.8 \\
Total & $\mathbf{2 1 3 6 9}$ & $\mathbf{1 0 0 . 0}$ \\
\hline
\end{tabular}


TABLE 3:

RESPONDENTS' CRITICAL THINKING ACROSS FIELDS OF STUDY

\begin{tabular}{|c|c|c|c|c|c|c|c|c|c|c|}
\hline \multirow{2}{*}{ Area of Discipline } & \multicolumn{2}{|c|}{ Least Satisfactory } & \multicolumn{2}{|c|}{ Unsatisfactory } & \multicolumn{2}{|c|}{ Fair } & \multicolumn{2}{|c|}{ Satisfactory } & \multicolumn{2}{|c|}{ Most Satisfactory } \\
\hline & $\begin{array}{c}\text { Count } \\
\text { (n) }\end{array}$ & $\%$ & Count (n) & $\%$ & $\begin{array}{c}\text { Count } \\
\text { (n) }\end{array}$ & $\%$ & Count (n) & $\%$ & Count (n) & $\%$ \\
\hline Arts \& Science Social & 61 & .7 & 192 & 2.3 & 61 & .7 & 1607 & 19.3 & 4007 & 48.2 \\
\hline Science & 46 & 1.0 & 227 & 4.9 & 46 & 1.0 & 1377 & 29.8 & 2091 & 45.3 \\
\hline Technical & 30 & 0.5 & 135 & 2.4 & 30 & 0.5 & 1047 & 18.3 & 2701 & 47.1 \\
\hline ICT & 12 & 0.8 & 32 & 2.0 & 12 & 0.8 & 243 & 15.3 & 712 & 44.8 \\
\hline Education & 9 & 0.8 & 15 & 1.3 & 9 & 0.8 & 190 & 17.1 & 597 & 53.6 \\
\hline Total & 158 & 0.7 & 601 & 2.8 & 158 & 0.7 & 4464 & 20.9 & 10108 & 47.3 \\
\hline
\end{tabular}

Nor Hashimah et.al (2009) report that only $20.8 \%$ of the graduates admit their critical thinking skills are most satisfactory while $55.1 \%$ admits that their critical thinking skills are satisfactory (Table 2). This is rather disheartening as critical skills are very essential in ensuring employability and marketability amongst the graduates. This data shows that a significant number of the graduates are in the category of having satisfactory, average and unsatisfactory critical thinking skills. This is not something that we can sweep under the carpet because critical thinking skills are crucial in an employee's life as this assists him or her in making decisions, problem solving and other challenging moves in their work environment. Although UPSI graduates do have a better chance of securing jobs as secondary school teachers but they must realize that Teaching institutes in the country which were formally Teacher training colleges are also having TESL courses for their students. Hence, this could pose a stiff competition in terms of getting their posting to schools.

It is not surprising that graduates are also not knowledgeable in critical thinking skills and its levels. This is found in a recent tracer study of Public university graduates of 2007. Nor Hashimah et.al (2009) realize although $53.9 \%$ of the education graduates admit that their Critical Thinking Skills are most satisfactory and they top compared to the other fields of study (Table 3). It is also important to note that these teachers do admit that their CT is merely satisfactory and least satisfactory. Perhaps, the future teachers feel they have satisfactory Critical thinking skills more than the other graduates because they did learn about them in their education courses at the universities. Let it be known that most education courses are taught in the Malay Language. Hence, it is understandable that the education graduates or teachers perceived their critical thinking skills as high compared to the others. What would have happened if their medium of instruction is English Language?

Another possible reason to the undergraduates' failure to incorporate higher level CT in their microteaching lessons is their nervousness and anxiety. The participants are greenhorns. The microteaching experience was their very first exposure to teaching in English despite having their friends as their secondary school students. This experience is a simulation of the real deal in schools yet their apprehension when teaching was easily detected. There are many reasons for their nervousness and anxiety. They are prepared because they have designed their lessons and instructions with visual aids, games, and video. They prepared their lesson plans well. The most glaring reason is their lack of vocabulary in English and that made them very nervous and insecure.

Nor Hashimah et.al (2009) investigate the relationship between 2007 graduate employability and marketability and the employability skills (soft skills) courses they attended prior to their graduation. This is a survey carried out by the Ministry of Higher Education. The study found that English Language is still a problem to be acquired by the graduates even for those with highly related jobs. It is alarming those who are employed by the government have low MUET (Malaysian University English Test) scores compared to the ones employed in local private companies. The Education graduates also rank the highest in having low MUET for highly related, fairly related and not related jobs. MUET stands for Malaysian University English Test and Education graduates are future secondary school teachers. What is to be expected of their teaching profession if their English Language is low? How can they be role models to encourage their students to listen, speak, read and write in English if their English is low? Undergraduates who are not living up to the expectation of future graduates can pose a big problem to the immensely competitive working organization.

\section{CONCLUSION AND RECOMMENDATIONS}

Critical thinking is indeed a difficult skill to grasp and it takes time to settle in the individuals. It is crucial that these future teachers of English include critical thinking skills in their lessons as they help mold future critical thinkers amongst the young Malaysians in schools. Therefore, it is a compelling necessity that these undergraduates' microteaching is unveil to detect the evidence of critical thinking and its disposition being included in their lessons or content instruction. The undergraduates have to really understand what Freiberg and Driscoll (1992) have in mind for teachers when they say this of critical thinking in the classroom:

Critical thinking is a process begins with questioning by you and by your students. Together, you engage in analysis, synthesis, and evaluation of events, information and ideas. The kind of thinking do before making a major purchase is critical because you look for options, weigh the advantages of your choice and reach a conclusion (p. 306).

The researchers have a few practical recommendations to help improve the undergraduates' critical thinking and its disposition. If considered, these suggestions can help these participants and other undergraduates to be better thinkers. 
Firstly, UPSI needs to set up a new course in critical thinking and its disposition. The Faculty of Languages may create a synergy with the faculty of Science Cognitive and Faculty of Education. This has to be a course in English Language where undergraduates are exposed to the fundamentals of CT and the different levels. In so doing, the lecturers involved may refer to practical suggestions such as the ones by Moore and Parker (2009). They provide an in depth essentials of critical thinking. It includes among others 'how well the student determine what information is or is not pertinent, separate facts from opinion, recognize that a problem may have no clear answer or single solution and propose other options and weigh them in the decision.' These are some of the 21 fundamentals that he offered. Without a doubt, it takes a good command of the English language to decipher the critical thinking essentials given by these authors. If the undergraduates lack in critical thinking what is to be of the future of their students. What is to be said of the future of young Malaysians if their teachers lack critical thinking skills? Teachers need to give this input so that the young people will be able to make decisions, solve problems and present their opinions and ideas in shaping the nation. This is the forceful obsession that drives and forms tomorrow and respectively the future of a nation. Freiberg and Driscoll (1992) are in agreement that "another example of content for tomorrow is higher level thinking or critical thinking. It is the kind of content that will cross other curriculum areas: that is you will be able to teach critical thinking while teaching something else". Secondly, UPSI can provide soft skills workshops in English for the undergraduates. Soft skills workshops can help equip undergraduates to be better at communication and critical thinking. This can focus on communication in the English Language. These workshops should start as early as their second year till their final year. The researcher understands the time, monetary and human constraints of these workshops but they are indeed worth it. The undergraduates will be exposed to critical thinking in English that includes its essentials. These workshops can help undergraduates acquire critical thinking skills as soft skills so that when they graduate they will be marketable. Potential employers look for potential employees who are dynamic, extrovert and who can use arguments with reasons to win more revenues for the company. Bowell and Kemp (2005) say 'an attempt to persuade by argument is an attempt to provide you with reasons for believing a claim, desiring something or doing something. They further stress that arguments appeal to a person's critical faculties that is his or her reason. Chafee (2004) advises us about the importance of making decisions so that we achieve greatness in our careers. He says that our jobs should be much more than a way to earn a pay check and the jobs should be vehicles for using our professional skills. They should also be opportunities for expressing our creative talents and stimulants to our personal growth and intellectual development. Chafee (2004) believes that our jobs should give experiences that provide us with feelings of fulfillment and self-esteem. University students should consider this advice before they pursue their future vocations.

Perhaps UPSI may use the nine strategies by Paul and Elder (2001). They believe prior to embracing the strategies we must accept the fact that there are serious problems in our thinking (accepting the challenge to our thinking) and begin regular practice through these stages:

Stage 1: The Unreflective Thinker (we are unaware of significant problems in our thinking)

Stage 2: The Challenged Thinker (we become aware of problems in our thinking)

Stage 3: The Beginning Thinker (we try to improve but without regular practice)

Stage 4: The Practicing Thinker (we recognize the necessity of regular practice)

Stage 5: The Advanced Thinker (we advance in accordance with our practice)

Stage 6: The Master Thinker (skilled \& insightful thinking become second nature to us)

Possibly UPSI can use Paton's idea of using the reflective journal to enhance critical thinking amongst the university students. Paton (2006) from the University of Sydney, Australia reports one student who reflects that he or she has learnt that university is a place to start build up his or her own value of the world and that things happen in the world is not simply good or bad but it is important to understand the story and the background of it. Hence, reflective journals are undeniably excellent to enhance university or college students thinking skills.

Another idea is to use collaborative learning rather than individual learning. Gokhale (2010) finds that students who participated in collaborative learning had performed significantly better on the critical thinking test than students who studied individually. Perhaps UPSI can design a course that incorporates collaborative learning so that students may work together with their peers in the hope of equiping themselves with critical thinking skills. Malaysia needs critical thinkers who will bring the country to greater heights.

\section{REFERENCES}

[1] Gokhale, A.A. (2010). Collaborative Learning Enhances Critical Thinking. Journal of Technology Education Vol. 7 No. 1, Fall 1995. http://sxholar.google.com/scholar?as_q-critical+ thinking+\&num=10\&btnG=Search +Scholar \& as_epq=\&a. retrieved 29 August 2010

[2] Bassham, G., Irwin, W., Nardone, H. \& Wallace, J.M. (2005). Critical Thinking. A Student's Introduction. 2nd edition. Boston: McGraw Hill.

[3] Bowell, T. \& Kemp, G. (2005). Critical Thinking. A Concise Guide. 2nd edition. New York: Routledge.

[4] Chaffee, J. (2004). Thinking Critically. A Concise Guide. New York: Houghton Mifflin Company.

[5] Effandi Zakaria \& Zanaton Iksan. (2007). Promoting Cooperative Learning in Science and Mathematical Education: A Malaysian Perspective. Eurasia Journal of Mathematics, Science and Technology Education, 3(1). 35-39. http:www.ejmste.com 
[6] Freeley, A.J. \& Steinberg, D.L. (2008). Argumentation and Debate: Critical Thinking for Reasoned Decision Making. $\mathrm{http} / / /$ books.google.com/books?hl=en\&lr=\&id=ZRCRxPGlOgQC\&oi=fnd\&pg=PR11\&dq=critical +thinking\& retrieved 31 August 2010

[7] Freiberg, J. \& Driscoll, A. (1992). Universal Teaching Strategies. Boston: Allyn \& Bacon.

[8] Lett, J. (2010). A Field Guide to Critical Thinking. Vol 14.4. http://www.csicop.org/si/show/field_guide_to_critical_thinkerretrieved 31 August 2010

[9] Moore, B.N. \& Parker, R. (2009). Critical Thinking 9th edition. New York: McGraw-Hill Higher Education.

[10] Nor Hashimah Isa, Rohana Jani \& Md. Yusof Abu Bakar. (2009). Employability Skills of 2007 Employed Public University Graduates: An inquiry. Ministry of Higher Learning, Malaysia.

[11] Norris, S. P. (1985). Synthesis of research on critical thinking. Educational Leadership, 40-45.

[12] Paton, M. (2006). Reflective Journal \& Critical Thinking. Symposium Presentation. http: //science.uniserve.edu.au/pubs/procs/2006/paton.pdf. 16 August 2009.

[13] Paul, R. \& Elder, L. (2001). Critical Thinking: Tools for Taking Charge of Your Learning and Your Life. http://www.criticalthinking.org/resources/books/tools-for-taking-charge.cfm. 23 August 2010

[14] Rajendran Nagappan. (2001). The Teaching of Higher-Order Thinking Skills in Malaysia. Journal of Southeast Asian Education, Vol. 2, No. 1.p 1-22. http://scholar.google.com/scholar?as_q=critical+ thinking $+\&$ num $=10 \& b \operatorname{tnG}=$ Search + Scholar \&as_epq=\&a. Retrieved 25 August 2010

[15] Wright, L. (2001). Critical Thinking. An Introduction to analytical reading and reasoning. New York: Oxford University Press.

[16] Paton, M. (2006). Symposium Presentation. Reflective journals and critical thinking. http://sydney.edu.au/science/uniserve_science/pubs/procs/2006/paton.pdf. Retrieved 25 August 2010

Nor Hashimah Isa is a senior lecturer of the English Language and Literature Department, Faculty of Languages and Communication, Universiti Pendidikan Sultan Idris (Sultan Idris Education University), Malaysia. Nor Hashimah holds a Ph.D in English Literature from Universiti Kebangsaan Malaysia (National University of Malaysia), an M.Ed in Curriculum and Instruction (English) from the University of Houston, Texas, USA and a Bachelor degree in TESL (Hons) from the Universiti Sains Malaysia (the Science University of Malaysia) Penang. The author's field of study is comparative literature, literatures in English and TESL Methodology.

She teaches English literature and Literatures in English to Bachelor, Masters and Advanced Diploma Students at the university. She is also the COORDINATOR of a compulsory university English language proficiency course called English for Communication II. She is the FACILITATOR for English for the Workplace, a course for the officers at the university. Her previous position was as a LECTURER of the English Language Department of the Federal Teacher Training College, Penang where she worked for five years. Prior to that, she taught English Language and Literature to Matriculation students of the Science University Malaysia in Penang. She has presented papers at international conferences of literature and English Language in Spain, Scotland, Australia and Germany. She is also the PEER REVIEWER for Universiti Teknologi MARA. Her books include Communicate Better - reading, listening and speaking for academic purposes(2000), Read Up Write Down-English for Communication 2(2010), Read up, Write down(2009), Zenith in Communicative English(2005) and Zenith in Communicative English Second Edition(2006). These books are all published by Universiti Pendidikan Sultan Idris. Her upcoming book is entitled Gusty Trail of May 13: Post-independence Malaysian Short Stories. Her current research is on the selection literary texts for Malaysian Secondary Schools where she is the RESEARCH LEADER. It is a two year FRGS or Fundamental Research Grant Scheme, fully sponsored by the Malaysian Ministry of Education.

Dr. Nor Hashimah Isa was a member of the Kappa Delta Phi when she was studying in the USA. Now, she is a member of the MLA. She also contributes to the education bureau of Persatuan Waris dan kerabat Negeri Perak, an association for the royalties of the state of Perak.

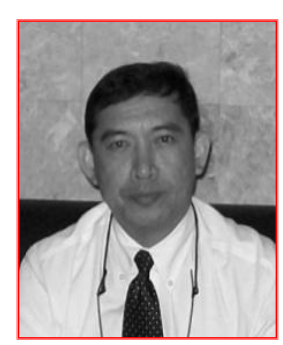

Hj. Kamaruzaman Jusoff was born in Kota Bharu, Kelantan, Malaysia, in 1958. He received the PhD in Forest Engineering from Cranfield University, England, UK in 1992. He is currently a Professor (Grade B) with Universiti Putra Malaysia and has been a Visiting Professor with The Harvard Forest, Harvard University, Kyoto's Graduate School of Engineering, Yale's Center for Earth Observation and an Erasmus Mundus Professor in Lund University, Sweden and ITC, The Netherlands. His field of expertise is in airborne hyperspectral image processing. Research and higher education leadership especially in creating succession planning models and talent pools have also being his current field of interests.

$\mathrm{Hj}$. Kamaruzaman has been very active in scholarly journals-book writing and publishing and has published 7 books and more than 250 citation index/impact factor journal papers. Administratively, used to hold several posts in UPM as Deputy Dean, Faculty of Forestry, UPM Kampus Bintulu Designate Director, MACRES Deputy Director (R\&D) while being active doing some consultancies on airborne hyperspectral sensing for forestry, agriculture, marine and Search-and-Rescue operations. 